\title{
Catalytic cracking of polyethylene plastic waste using synthesised zeolite Y from Nigerian kaolin deposit
}

\author{
Abosede A. Ajibola ${ }^{1}$. James A. Omoleye ${ }^{1} \cdot$ Vincent E. Efeovbokhan $^{1}$
}

Received: 1 June 2018 / Accepted: 2 November 2018 / Published online: 12 November 2018

(c) The Author(s) 2018

\begin{abstract}
The increasing rate of accumulation of plastic waste (PW) is quite disturbing to the world, particularly in developing nations due to its non-biodegradable nature and inadequate waste management practices. The need to properly manage this waste and utilize the potential and chemical energy value that can be derived from this waste justifies the encouragement and employment of newer and better recycling methods and technology of these wastes. Therefore, this has led us to explore the catalytic pyrolysis of plastic waste using zeolite Y synthesized from kaolin deposit in Covenant University, Sango Ota, Ogun state of Nigeria. A stainless steel packed bed reactor was used in the cracking of low-density polyethylene (LDPE) plastic wastes into liquid fuel components at a temperature of $300{ }^{\circ} \mathrm{C}$ using zeolite $\mathrm{Y}$ catalyst. The liquid fuel obtained from the catalytic pyrolysis was analyzed using GC-MS. Fifty compounds were identified, which revealed the presence of mostly alkenes and aromatics in the hydrocarbons range of $\mathrm{C}_{8}-\mathrm{C}_{29}$. This is made up of $56 \%$ of gasoline fractions range of $\mathrm{C}_{6}-\mathrm{C}_{12}, 26 \%$ of diesel and kerosene fractions range $\mathrm{C}_{13}-\mathrm{C}_{18}$, and $10 \%$ of fuel oil range $\mathrm{C}_{18}-\mathrm{C}_{23}$, while $8 \%$ is residual fuel range greater than $\mathrm{C}_{24}$.
\end{abstract}

Keywords Polyethylene $(\mathrm{PE}) \cdot$ Catalytic cracking $\cdot$ Pyrolysis $\cdot$ Zeolite Y $\cdot$ GC-MS

\section{Introduction}

The use of plastic material is of greater importance in our daily lives and its consumption has led to the drastic increase of PW in the second half of the twentieth century [1]. The demand for plastics has increased over time because they are considered as alternative materials providing solutions to various sectors such as aerospace, engineering, medicals, and electronics [2]. Polyethylene plastics are nonbiodegradable, lightweight, and flexible materials and are extremely important for technology advancement due to these properties.

$\mathrm{PW}$ is the major constituent of municipal solid waste (MSW) and seen as fast approaching one of the largest MSWs in the developing countries [3]. The accumulation

Abosede A. Ajibola

adesinasibose@gmail.com

James A. Omoleye

james.abiodune@covenantuniversity.edu.ng

Vincent E. Efeovbokhan

vincent.efeovbokhan@ covenantuniversity.edu.ng

1 Department of Chemical Engineering, College of Engineering, Covenant University, Ota, Nigeria of this PW over a length of time in conjunction with the improper and conventional waste management strategies have led to major health and environmental hazards such as greenhouse gas emissions, groundwater pollution, and several other human health problems [4]. In addition, developing countries do not consider the advantages of economic gain involved by utilizing certain recycling methods, but still depend solely on the conventional method of landfilling of MSW disposal.

Hence, effort toward the conversion of this PW to resourceful materials of valuable products and energy, in addition to solving the shortage of natural resources, in the nearest future has been a major area of research [2]. This can be achieved by exploring recycling methods, which so far is the best option for PW management [5]. PW recycling methods have been mainly grouped into four major types, namely primary recycling involves waste scraps being processed into products with similar properties to the original products; secondary recycling has to do with waste/scrap plastics being processed into materials that have different properties to that of the initial product; tertiary methods deal with use of these waste scraps in the production of essential fuels and chemicals or as a segregated waste; and lastly quaternary recycling involves the burning of these plastics

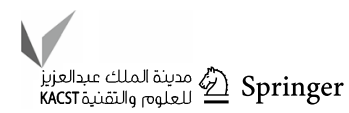


and retrieving energy contents afterward [6]. Each of these recycling methods is advantageous and effective for different applications.

Thermoplastics and thermosets are the main types of plastic used for daily consumptions. Upon the introduction of heat, thermoplastics become soft and later harden up, while thermosets harden irreversibly. There are six main components of MSW, namely: polyethylene (PE), there are two major types and make up about $40 \%$ of the MSW which are low-density polyethylene (LDPE) and high-density polyethylene (HDPE), polyethylene terephthalate (PET), polyvinyl chloride (PVC), polystyrene (PS), and polypropylene (PP) $[2,7]$.

Thermal cracking, or pyrolysis, involves the degradation of the long chain polymeric materials by heating in the absence of oxygen. Gas, oil, and char are the three major products obtained during the pyrolysis process and these products are of great value to the production and refinery industries [8]. Compared to other MSW management practices, pyrolysis is more desirable and satisfactory environmentally because it reduces the carbon footprint of products. Pyrolysis process also lessens the amount of carbon monoxide and carbon dioxide emissions by making effective use of an inert atmosphere that is free of oxygen to avoid the formation of dioxins through product reaction with oxygen $[9,10]$. This pyrolysis process is a cleaner technology, a drive toward energy security and a measure to combat fossil fuel depletion.

Zeolites are crystalline microporous aluminosilicate materials with an extra framework having ion exchange capabilities and thermal stability over a wide temperature range. They are currently used as catalysts for catalytic cracking of heavy hydrocarbons in many commercial processes; zeolite $\mathrm{Y}$ is a highly porous faujasite zeolite with $\mathrm{Si} /$ $\mathrm{Al}$ ratio of 1.5-3.8 [11, 12].

Zeolites are produced both naturally and synthetically; however, those that find applications in the petroleum and petrochemical industries are mainly the synthetic ones. The synthesis of zeolites from clay as a source of silica and alumina is widely known and has yielded great achievement $[13,14]$. Arobieye clay in Nigeria was found to have a cost advantage of $25 \%$ over the commercial chemical in the synthesis of zeolite. This kaolin clay is in abundance in many parts of Nigeria and previous works have shown that it is a rich alternative source for obtaining alumina [15].

There have been a number of published articles on the catalytic degradation of PE plastics, particularly the LDPE. For example, Neves et al. [1] undertook the catalytic pyrolysis of polyethylene using zeolite. Almeida et al. [16] also investigated the thermal and catalytic pyrolysis of PW and obtained products with a high added value such as fuel oils and feedstock for new products. Kunwar et al. [17] investigated the catalytic and thermal depolymerization of lowvalue post-consumer high-density polyethylene plastic. Thermal cracking yielded mainly diesel and vacuum gas oil fractions, while catalytic cracking (using $\mathrm{Y}$ zeolite and $\mathrm{MgCO}_{3}$ ) yielded increased gasoline and diesel-range fractions. The fuel properties of the diesel-range distillate were found comparable to those of ultralow sulfur diesel (ULSD). Adeoye et al. [18] synthesized zeolite $\mathrm{Y}$ with $\mathrm{Si} / \mathrm{Al}$ ratio of 3.22 from Arobieye clay in Nigeria and further tested its catalytic effect on cyclohexane.

This work seeks to further investigate and evaluate the activity of this zeolite $\mathrm{Y}$ on the cracking of LDPE PW. The success of this work will enhance the effectiveness of plastic waste processing to useful products in Nigeria and Africa in general in an economically affordable manner and hence reduce the environmental hazard posed by their indiscriminate dumping.

\section{Experimental}

\section{Materials}

LDPE was used in this experiment. The PPW was obtained from waste bins and garbage from Ota, south-west Nigeria. It was then sorted, cleaned to remove dirt, and then shredded into smaller particle sizes. The catalyst used was a Covenant University pilot plant-synthesized zeolite Y from Arobieye kaolin deposit in Nigeria with an $\mathrm{Si} / \mathrm{Al}$ ratio of 1.45 which is rich in oxides of calcium, iron, and titanium.

\section{Characterization of catalyst used}

$\mathrm{X}$-ray diffraction (XRD) patterns were recorded on an $\mathrm{X}$-ray diffraction machines to know the relative crystallinity and crystal structure of synthesized zeolite using a $\mathrm{Cu}-\mathrm{Ka}$ radiation with the wavelength of 1.540598 . Scanning electron micrograph (SEM) was analyzed by phenom prox SEM with the model number 800-07334 and part number MVE0224651193 used to determine the morphology of the zeolite.

The chemical composition of both the raw Arobieye kaolin and synthesized zeolite was analyzed using X-ray fluorescence (XRF).

\section{Experimental procedures}

LDPE was collected and prepared by cutting into smaller particle sizes of 3-4 $\mathrm{mm}$ and charged into a packed bed pyrolysis reactor which was operated at a temperature of 


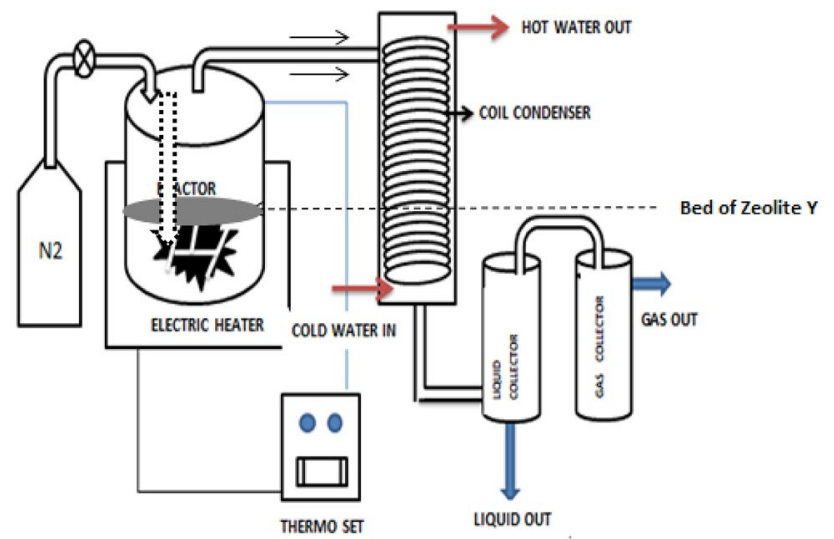

Fig. 1 Schematic representation of the pyrolysis setup. Source: Ajibola et al. (this study)

$300{ }^{\circ} \mathrm{C}$ and at atmospheric pressure. As shown in Fig. 1, the reactor is a lagged cylindrically shaped stainless steel vessel of capacity $300 \mathrm{ml}$ with a height of $11 \mathrm{~cm}$ and diameter of $6 \mathrm{~cm}$. The reactor was electrically heated with a $2 \mathrm{~kW}$ heating element equipped with an automatic temperature controller and connected to a coil condenser, and subsequently liquid and gas collectors.

$100 \mathrm{~g}$ of polymer to $10 \mathrm{~g}$ of catalyst was used in the experiment and fed into the reactor, tightly closed, and purged with nitrogen gas at the start of each experiment at the rate of $20 \mathrm{ml} / \mathrm{min}$ for $10 \mathrm{~min}$. The heating element was turned on and regulated to a specified temperature to liquefy the PPW. The liquefied PPW at the set temperature was vaporized. The vaporized PPW passed through the catalyst bed where reaction occurred. The vaporized product was finally condensed and collected for analysis. The solid (S), gaseous (G), and liquid product (L) yields were calculated using the formula given below as shown in Eqs. 1, 2, 3 (Source: Patil [19]):

$\mathrm{L}(\mathrm{wt} \%)=\frac{\text { weight of liquid product }}{\text { weight of plastic feed }} \times 100$,

$\mathrm{S}(\mathrm{wt} \%)=\frac{\text { weight of solid product }}{\text { weight of plastic feed }} \times 100$,

$\mathrm{G}(\mathrm{wt} \%)=100-(\mathrm{L}(\mathrm{wt} \%)+\mathrm{S}(\mathrm{wt} \%))$.

\section{Analytical methods}

The pyrolyzed oil was analyzed using gas chromatography-mass spectrometry (GC-MS) to determine the chemical constituents of the hydrocarbon products. The GC-MS and column oven temperature conditions used are stated in Table 1.

\section{Identification of components}

Mass spectrum GC-MS was interpreted using the National Institute Standard and Technology (NIST) library of mass spectra database. Comparison of the unknown and known spectrum components was done using the NIST library. The molecular name and weight of the compounds were also confirmed.

\section{Results and discussion}

Table 2 shows the XRF analysis of the synthesized zeolite $\mathrm{Y}$, which shows $\mathrm{SiO}_{2} / \mathrm{Al}_{2} \mathrm{O}_{3}$ of 3.22 in comparison with the chemical composition of the raw Arobieye kaolin used which shows a $\mathrm{SiO}_{2} / \mathrm{Al}_{2} \mathrm{O}_{3}$ of 1.45 . These results show that the $\mathrm{Si} / \mathrm{Al}$ ratios are within the expected ranges of 1-2 and 1.5-3.8, respectively $[12,20]$. Figure 2 shows the XRD pattern of the synthesized zeolite $\mathrm{Y}$ with peaks observed at Bragg's angles of 14, 19, 21, 24, 26.8, 31.9, 34.9, 39.9, 49.8, and $51^{\circ}$ [21]. Figure 3 also shows the structural morphology of the synthesized zeolite at a magnification of 3500 depicting clear crystal formation of zeolite $\mathrm{Y}$ from the structural boundaries and shapes.

The results from the GC-MS analysis established the identity of the number of compounds or fractions of the liquid fuel obtained from the cracked PPW. Identification of compounds was also done through mass spectrometry attached with GC. Figure 4 and Table 3 show the yield of the pyrolyzed PPW at a temperature of $300{ }^{\circ} \mathrm{C}$. From this result, it can be seen that the liquid yield is more than that of other products. The liquid fuel extracts were yellow in color.

\section{Characterization of liquid products}

The pyrolyzed PPW reveals the presence of hydrocarbons in the $\mathrm{C}_{8}-\mathrm{C}_{29}$ range. Analyzing the compounds present in the liquid fuel of the catalytically pyrolyzed LDPE, it can be deduced from Fig. 5 that the carbon number distribution of LDPE contains the gasoline $\left(\mathrm{C}_{6}-\mathrm{C}_{12}\right)$ fraction of $56 \%$, diesel and kerosene $\left(\mathrm{C}_{13}-\mathrm{C}_{18}\right)$ fraction of $26 \%$, and fuel oil $\left(\mathrm{C}_{19}-\mathrm{C}_{23}\right.$ fraction of $10 \%$, while the residual fuel oil $\left(>\mathrm{C}_{24}\right)$ fraction range was $6 \%$.

Although the functional group in this present study was not detected. From literature review, the most abundant 
Table 1 GC/MS condition. Source: Ajibola et al. (this study)

GC-MS Agilent

433UI HP-5 ms ultra inert

\begin{tabular}{|c|c|c|c|}
\hline Column oven temperature & & \multicolumn{2}{|l|}{$50{ }^{\circ} \mathrm{C}$} \\
\hline Injection mode & & \multicolumn{2}{|l|}{ Split } \\
\hline Injection temperature & & \multicolumn{2}{|c|}{$150^{\circ} \mathrm{C}$} \\
\hline Injection volume & & \multicolumn{2}{|l|}{$1 \mathrm{ml}$} \\
\hline Split ratio & & \multicolumn{2}{|l|}{$10: 1$} \\
\hline Average velocity & & \multicolumn{2}{|c|}{$36.445 \mathrm{~cm} / \mathrm{sec}$} \\
\hline Column pressure & & \multicolumn{2}{|c|}{$7.6522 \mathrm{psi}$} \\
\hline Column flow & & \multicolumn{2}{|c|}{$1.2211 \mathrm{ml} / \mathrm{min}$} \\
\hline Carrier gas & & \multicolumn{2}{|c|}{ Helium $99.9995 \%$ purity } \\
\hline Frequency & & \multicolumn{2}{|l|}{$50 \mathrm{~Hz}$} \\
\hline Electron multiplier volts & & \multicolumn{2}{|c|}{1024.9} \\
\hline \multicolumn{4}{|c|}{ Colum oven temperature progress } \\
\hline Rate $\left({ }^{\circ} \mathrm{C} / \mathrm{min}\right)$ & Temperature $\left({ }^{\circ} \mathrm{C}\right)$ & & $\begin{array}{l}\text { Hold } \\
\text { time } \\
(\mathrm{min})\end{array}$ \\
\hline- & 50 & & 0 \\
\hline 8 & 300 & & 9 \\
\hline \multicolumn{4}{|l|}{ Column } \\
\hline Length & & \multicolumn{2}{|l|}{$30.0 \mathrm{~m}$} \\
\hline Diameter & & \multicolumn{2}{|l|}{$250 \mu \mathrm{m}$} \\
\hline Film thickness & & \multicolumn{2}{|l|}{$0.25 \mu \mathrm{m}$} \\
\hline Total runtime & & \multicolumn{2}{|l|}{$32 \mathrm{~min}$} \\
\hline \multicolumn{4}{|l|}{ MS conditions } \\
\hline Source temperature & & & $230{ }^{\circ} \mathrm{C}$ \\
\hline Start mass range $m / z$ & & & 50 \\
\hline End mass range $\mathrm{m} / \mathrm{z}$ & & & 550 \\
\hline
\end{tabular}

Table 2 XRF analysis of the raw Arobieye kaolin and synthesized zeolite. Source: Adeoye et al. [18]

\begin{tabular}{lcc}
\hline Chemical composition & Raw Arobieye kaolin & $\begin{array}{l}\text { Synthesized } \\
\text { zeolite } \mathrm{Y}\end{array}$ \\
\hline $\mathrm{SiO}_{2}$ & 48.79 & 39.71 \\
$\mathrm{Al}_{2} \mathrm{O}_{3}$ & 33.58 & 20.94 \\
$\mathrm{Fe}_{2} \mathrm{O}_{3}$ & 2.65 & 2.26 \\
$\mathrm{CaO}$ & 2.98 & 3.15 \\
$\mathrm{MgO}$ & 0.58 & 0.28 \\
$\mathrm{SO}_{3}$ & 0.04 & 6.76 \\
$\mathrm{Na}_{2} \mathrm{O}$ & 0.07 & 28.47 \\
$\mathrm{~K}_{2} \mathrm{O}$ & 0.01 & 0.06 \\
$\mathrm{TiO}_{2}$ & 1.48 & 1.67 \\
$\mathrm{P}_{2} \mathrm{O}_{5}$ & 0.10 & 0.07 \\
$\mathrm{Mn}_{2} \mathrm{O}_{3}$ & 0.01 & 0.02 \\
$\mathrm{Si} / \mathrm{Al}$ (wt $\%)$ & 1.45 & 3.22 \\
\hline
\end{tabular}

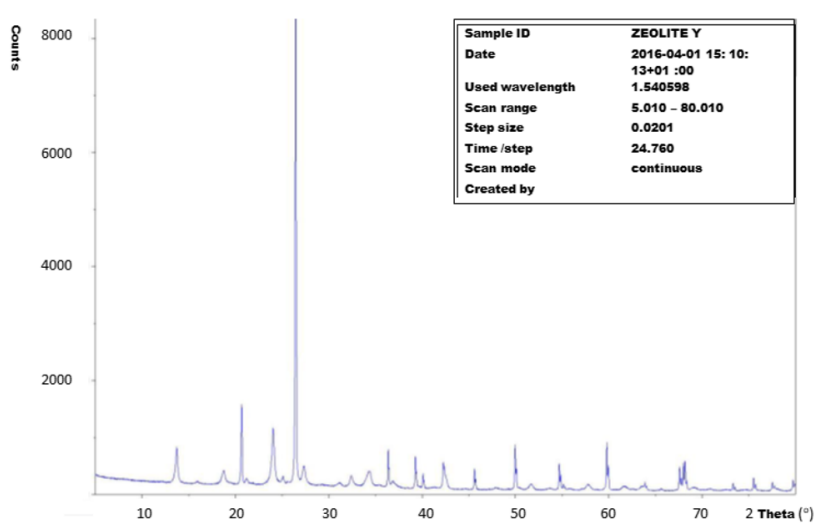

Fig. 2 XRD pattern for the synthesized zeolite Y. Source: Adeoye et al. [18] 


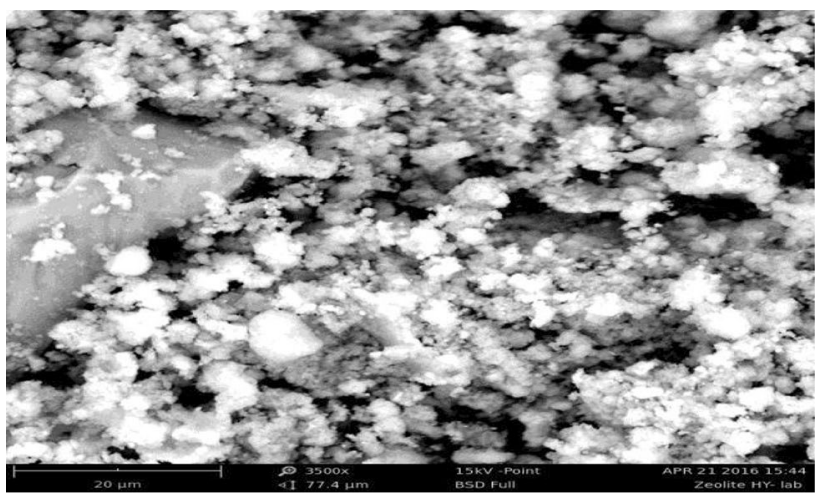

Fig. 3 SEM images for the synthesized zeolite Y. Source: Adeoye et al. [18]

\section{Product Yield from Pyrolysis of PPW}

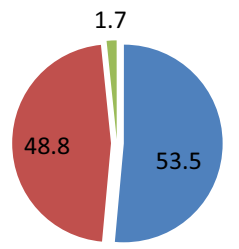

\section{- LIQUID YIELD \\ - GASEOUS YIELD \\ - SOLID RESIDUE}

Fig. 4 Product yield of pyrolyzed PPW at temperature of $300{ }^{\circ} \mathrm{C}$. Source: Ajibola et al. (this study)

Table 3 Yields of liquid, gas, and solid residue from pyrolyzed PPW. Source: Ajibola et al. (this study)

\begin{tabular}{llll}
\hline Products & Yield wt $\%$ & Hydrocarbon ranges & Yield wt $\%$ \\
\hline Liquid & 53.5 & $\mathrm{C}_{6}-\mathrm{C}_{12}$ & 56 \\
& & $\mathrm{C}_{13}-\mathrm{C}_{18}$ & 26 \\
& & $\mathrm{C}_{19}-\mathrm{C}_{24}$ & 10 \\
& & $>\mathrm{C}_{12}$ & 6 \\
Gaseous & 44.8 & & \\
Solid residue & 1.7 & & \\
\hline
\end{tabular}

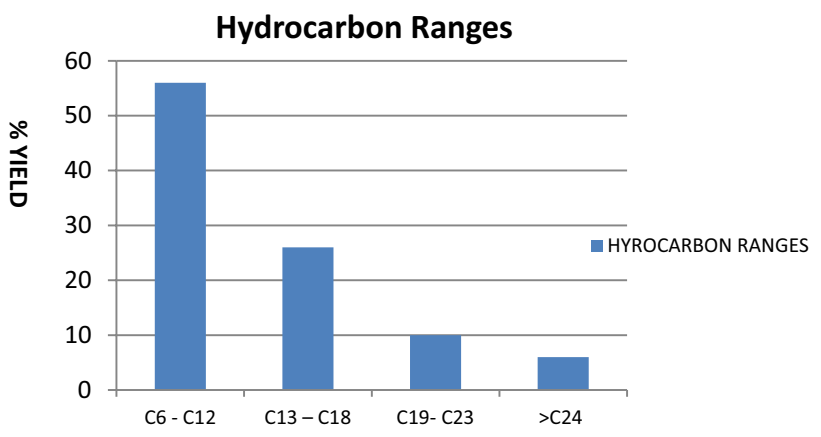

Fig. 5 Hydrocarbon ranges of the liquid fuel composition. Source: Ajibola et al. (this study)

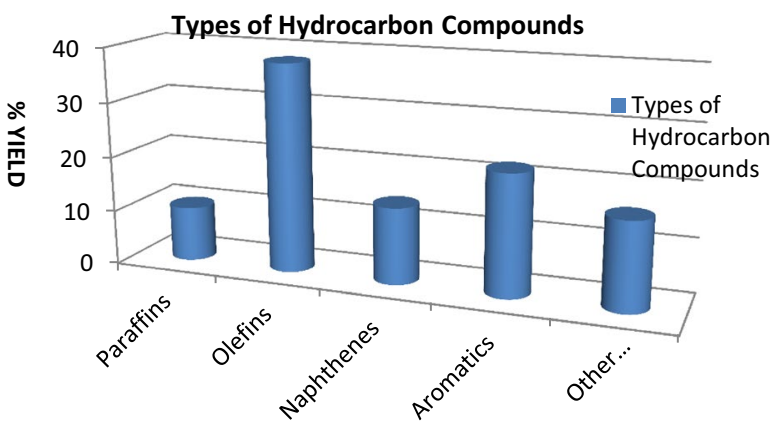

Fig. 6 Functional groups of the liquid fuel composition. Source: Ajibola et al. (this study)

groups were alkenes, alkanes, and aromatics [19]. From Fig. 6, the compound obtained from the pyrolyzed PPW shows the presence of several functional groups such as paraffins, olefins, naphthenes, aromatics, aldehydes, and esters. It shows that olefins and aromatics are the major compounds present $[22,23]$.

This present study reveals that the catalytic pyrolysis of LDPE plastic has yielded a higher fraction of gaseous product and lesser liquid fraction when compared to our previous work on non-catalytic thermal cracking of this plastic waste. This also agrees with the work of Seo et al. [24] that showed an increase of gaseous product from 13 to $63.5 \%$ using a catalyst for the pyrolysis reaction.

Fifty compounds were detected as shown in Table 4, and the five major compounds confirmed were styrene (4.96\%), cyclopropane, nonyl (4.65\%), indecene (4.32\%), Z-5-nonadecene $(3.73 \%)$, and indene (3.02\%) with the retention times of 4.391, 7.27, 11.269, 20.104, and $6.909 \mathrm{~min}$, respectively. The compounds obtained here were similar to those obtained by Patil et al. [19].

\section{Conclusion}

The catalytic cracking of the LDPE plastic wastes using zeolite $\mathrm{Y}$ has revealed the great usefulness of this waste as a rich source of raw materials for the production of a variety of chemicals and a good alternative to the production of automobile fuel.

GC-MS showed the compositional analysis of the liquid fuel obtained containing mainly aliphatic and aromatic compounds in the carbon range of $\mathrm{C}_{8}-\mathrm{C}_{29}$. The liquid products obtained have similar products to fossil fuels and can, therefore, be used as alternative fuels for a more sustainable 
Table 4 Chemical compositions of the liquid fuel products obtained from the catalytic pyrolysis of LDPE

\begin{tabular}{|c|c|c|c|c|c|}
\hline Peak & Retention time & Area $\%$ & Compound & Molecular formula & Molecular weight \\
\hline 1 & 3.625 & 1.21 & 2,4-dimethyl-1-heptene & $\mathrm{C}_{9} \mathrm{H}_{18}$ & 126.2392 \\
\hline 2 & 3.916 & 1.36 & Benzene, 1,3-dimethyl- & $\mathrm{C}_{8} \mathrm{H}_{10}$ & 106.1650 \\
\hline 3 & 4.037 & 1.25 & Benzene, 1,3-dimethyl- & $\mathrm{C}_{8} \mathrm{H}_{10}$ & 106.1650 \\
\hline 4 & 4.391 & 4.96 & Styrene & $\mathrm{C}_{8} \mathrm{H}_{8}$ & 104.1491 \\
\hline 5 & 4.62 & 1.08 & 1-(2-propenyl)cyclopentene & $\mathrm{C}_{8} \mathrm{H}_{12}$ & 108.1809 \\
\hline 6 & 5.187 & 1.35 & 1-(2-propenyl)cyclopentene & $\mathrm{C}_{8} \mathrm{H}_{12}$ & 108.1809 \\
\hline 7 & 5.45 & 1.06 & Benzene, 1-ethyl-4-methyl- & $\mathrm{C}_{9} \mathrm{H}_{12}$ & 120.1916 \\
\hline 8 & 5.765 & 2.01 & 1,9-Decadiene & $\mathrm{C}_{10} \mathrm{H}_{18}$ & 138.2499 \\
\hline 9 & 5.982 & 2.92 & 1-Decene & $\mathrm{C}_{10} \mathrm{H}_{20}$ & 140.2658 \\
\hline 10 & 6.051 & 1 & Bicyclo[4.2.0]octa-1,3,5-triene- methyl & $\mathrm{C}_{8} \mathrm{H}_{8}$ & 104.1491 \\
\hline 11 & 6.554 & 1.04 & Bicyclo[4.2.0]octa-1,3,5-triene & $\mathrm{C}_{8} \mathrm{H}_{8}$ & 104.1491 \\
\hline 12 & 6.749 & 1.13 & Indane & $\mathrm{C}_{9} \mathrm{H}_{10}$ & 118.1757 \\
\hline 13 & 6.909 & 3.02 & Indene & $\mathrm{C}_{9} \mathrm{H}_{8}$ & 116.1598 \\
\hline 14 & 7.447 & 0.99 & Bicyclo[4.1.0]heptane,3-methyl & $\mathrm{C}_{8} \mathrm{H}_{14}$ & 110.1095 \\
\hline 15 & 7.55 & 2.73 & 5-Undecyne & $\mathrm{C}_{11} \mathrm{H}_{20}$ & 152.2765 \\
\hline 16 & 7.27 & 4.65 & Cyclopropane, nonyl- & $\mathrm{C}_{12} \mathrm{H}_{24}$ & 168.3190 \\
\hline 17 & 7.859 & 1.22 & Undecane & $\mathrm{C}_{11} \mathrm{H}_{24}$ & 156.3083 \\
\hline 18 & 8.809 & 2.87 & 2-Methylindene & $\mathrm{C}_{10} \mathrm{H}_{10}$ & 130.1864 \\
\hline 19 & 8.906 & 1.87 & 2-Methylindene & $\mathrm{C}_{10} \mathrm{H}_{10}$ & 130.1864 \\
\hline 20 & 9.072 & 0.99 & $\begin{array}{l}\text { Tetracyclo }[5 \cdot 3 \cdot 0.0<2,6>.0<3,10>] \mathrm{deca}-4,8 \text {-di- } \\
\text { ene }\end{array}$ & $\mathrm{C}_{10} \mathrm{H}_{10}$ & 130.1864 \\
\hline 21 & 9.341 & 1.8 & 1,11-Dodecadiene & $\mathrm{C}_{12} \mathrm{H}_{22}$ & 166.3031 \\
\hline 22 & 9.461 & 2.46 & Azulene & $\mathrm{C}_{10} \mathrm{H}_{8}$ & 128.1705 \\
\hline 23 & 9.667 & 1.12 & Dodecane & $\mathrm{C}_{12} \mathrm{H}_{26}$ & 170.3348 \\
\hline 24 & 9.724 & 1.07 & 2-Dodecene, (Z)- & $\mathrm{C}_{12} \mathrm{H}_{24}$ & 168.3190 \\
\hline 25 & 10.846 & 1.11 & 1H-indene, 1,3-dimethyl- & $\mathrm{C}_{11} \mathrm{H}_{12}$ & 144.2130 \\
\hline 26 & 11.092 & 2.62 & 17-Octadecynoic acid & $\mathrm{C}_{18} \mathrm{H}_{32} \mathrm{O}_{2}$ & 280.4455 \\
\hline 27 & 11.269 & 4.32 & 1-Tridecene & $\mathrm{C}_{13} \mathrm{H}_{26}$ & 182.3455 \\
\hline 28 & 11.389 & 2.21 & Naphthalene, 1-methyl- & $\mathrm{C}_{11} \mathrm{H}_{10}$ & 142.1971 \\
\hline 29 & 11.693 & 1.64 & Naphthalene, 2-methyl- & $\mathrm{C}_{11} \mathrm{H}_{10}$ & 142.1971 \\
\hline 30 & 11.778 & 1.22 & Cyclohexasiloxane, dodecamethyl- & $\mathrm{C}_{12} \mathrm{H}_{36} \mathrm{O}_{6} \mathrm{Si}_{6}$ & 444.9236 \\
\hline 31 & 12.763 & 2.03 & 1,13-Tetradecadiene & $\mathrm{C}_{14} \mathrm{H}_{26}$ & 194.3562 \\
\hline 32 & 12.946 & 2.95 & 1-Tetradecene & $\mathrm{C}_{14} \mathrm{H}_{28}$ & 196.3721 \\
\hline 33 & 13.804 & 1.21 & Naphthalene, 1,6-dimethyl- & $\mathrm{C}_{12} \mathrm{H}_{12}$ & 156.2237 \\
\hline 34 & 14.37 & 1.7 & cis-9-Tetradecen-1-ol & $\mathrm{C}_{14} \mathrm{H}_{28} \mathrm{O}$ & 212.3715 \\
\hline 35 & 14.502 & 2.21 & Chloroacetic acid, pentadecyl este & $\mathrm{C}_{17} \mathrm{H}_{33} \mathrm{ClO}_{2}$ & 304.899 \\
\hline 36 & 15.893 & 1.9 & Pentadecanal- & $\mathrm{C}_{15} \mathrm{H}_{30} \mathrm{O}$ & 226.3981 \\
\hline 37 & 17.323 & 1.77 & cis-9-Tetradecen-1-ol & $\mathrm{C}_{14} \mathrm{H}_{28} \mathrm{O}$ & 212.3715 \\
\hline 38 & 17.455 & 1.54 & 3-Heptadecene, (Z)- & $\mathrm{C}_{17} \mathrm{H}_{34}$ & 238.452 \\
\hline 39 & 18.799 & 1.26 & 1-Octadecene & $\mathrm{C}_{18} \mathrm{H}_{36}$ & 252.4874 \\
\hline 40 & 19.984 & 1.11 & Oxirane, hexadecyl- & $\mathrm{C}_{18} \mathrm{H}_{36} \mathrm{O}$ & 268.4778 \\
\hline 41 & 20.104 & 3.44 & Z-5-Nonadecene & $\mathrm{C}_{19} \mathrm{H}_{38}$ & 266.513 \\
\hline 42 & 22.507 & 2.9 & 1-Nonadecene & $\mathrm{C}_{19} \mathrm{H}_{38}$ & 266.513 \\
\hline 43 & 23.657 & 2.25 & 1-Nonadecene & $\mathrm{C}_{19} \mathrm{H}_{38}$ & 266.513 \\
\hline 44 & 24.704 & 2.04 & 9-Tricosene, $(Z)-$ & $\mathrm{C}_{23} \mathrm{H}_{46}$ & 322.621 \\
\hline 45 & 25.746 & 2.5 & Cyclotetracosane & $\mathrm{C}_{24} \mathrm{H}_{48}$ & 336.6379 \\
\hline 46 & 26.724 & 1.51 & 1-Nonadecene & $\mathrm{C}_{19} \mathrm{H}_{38}$ & 266.513 \\
\hline 47 & 28.59 & 2.95 & Octadecane & $\mathrm{C}_{18} \mathrm{H}_{38}$ & 254.4943 \\
\hline 48 & 29.448 & 2.46 & Tetracosane & $\mathrm{C}_{24} \mathrm{H}_{50}$ & 338.6538 \\
\hline 49 & 30.278 & 1.85 & Nonacosane & $\mathrm{C}_{29} \mathrm{H}_{60}$ & 408.7867 \\
\hline 50 & 31.09 & 1.33 & Hexadecane, 1-iodo- & $\mathrm{C}_{16} \mathrm{H}_{33} \mathrm{I}$ & 352.3377 \\
\hline
\end{tabular}


and cleaner environment when necessary blending is done for upgrading.

Open Access This article is distributed under the terms of the Creative Commons Attribution 4.0 International License (http://creativeco mmons.org/licenses/by/4.0/), which permits unrestricted use, distribution, and reproduction in any medium, provided you give appropriate credit to the original author(s) and the source, provide a link to the Creative Commons license, and indicate if changes were made.

\section{References}

1. Neves IC, Botelho G, Machado AV (2007) Catalytic degradation of polyethylene : an evaluation of the effect of dealuminated Y zeolites using thermal analysis. Mater Chem Phys 104:5-9

2. Al-salem SM, Antelava A, Constantinou A, Manos G, Dutta A (2017) A review on thermal and catalytic pyrolysis of plastic solid waste. J Environ Manage 197(1408):177-198

3. Shah SH et al (2010) Low temperature conversion of plastic waste into light hydrocarbons. J Hazard Mater 179(1-3):15-20

4. UNEP (2009) Converting waste plastics into a resource. Osaka, pp. $1-15$

5. Schiers J (2006) Feedstock recycling and pyrolysis of waste plastics: converting waste plastics into diesel and other fuels. Wiley, Chichester

6. Al-Salem SM (2009) Establishing an integrated databank for plastic manufacturers and converters in Kuwait. J Waste Manag 29:479-484

7. Onwudili JA, Insura N, Williams PT (2009) Composition of products from the pyrolysis of polyethylene and polystyrene in a closed batch reactor: effects of temperature and residence time. J Anal Appl Pyrolysis 86(2):293-303

8. Sharuddin A, Faisal A, Daud WM, Aroua MK (2016) A review on pyrolysis of plastic wastes. Energy Convers Manag 115:308-326

9. Singh RK, Ruj B (2016) Time and temperature depended fuel gas generation from pyrolysis of real-world municipal plastic waste. $\mathrm{J}$ Fuel 104:164-171

10. Chen D, Yin L, Wang H, He P (2014) Pyrolysis technologies for municipal solid waste: a review. J Waste Manag 34:2466-2486
11. Sakaki AS, Roozbehani B, Shishesaz M, Nasrin A (2013) Catalytic degradation of the mixed polyethylene and polypropylene into middle distillate products. Clean Technol Environ Policy 16:901-910

12. Auerbach SM, Carrado KA, Dutta PK (2003) Zeolite science and technology, New York, Basel, pp. 11-30

13. Chandrasekhar S, Pramada PN (1998) Investigation on the synthesis of zeolite NaX from Kerala kaolin. J Porous Mater 6:283-284

14. Liu X, Yan Z, Wang H, Luo Y (2003) In-situ synthesis of NaY zeolite with coal-based kaolin. J Nat Gas Chem 12:63-70

15. Ajayi AO, Atta AY, Aderemi BO, Adefila SS (2010) Novel method of metakaolin dealumination preliminary investigation. J Appl Sci Res 6(10):1539-1546

16. Almeida D, Marques MDF (2015) Thermal and catalytic pyrolysis of plastic waste. Polimeros J 26:44-51

17. Kunwar B, Moser BR, Chandrasekaran SR, Rajagopalan N, Sharma BK (2016) Catalytic and thermal depolymerization of low value post-consumer high density polyethylene plastic. Energy 111:884-892

18. Adeoye JB, Omoleye JA, Ojewunmi ME (2016) Synthesis of zeolite $\mathrm{Y}$ from kaolin using novel method of alumination. Int J Appl 12(05):755-760

19. Patil L, Varma K, Gajendra S, Mondal P (2017) Thermocatalytic degradation of high density polyethylene into liquid product. $\mathrm{J}$ Polym Environ 1-10

20. Atta AY, Ajayi OA, Adefila SS (2007) Synthesis of faujasite zeolites from kankara kaolin clay. J Appl Sci Res 3(10):1017-1021

21. Robson H, Lillerud KP (2001) Verified syntheses of zeolitic materials, 2nd edn, Amsterdam, Netherlands, Elsevier

22. Marcilla A, Beltra MI, Navarro R (2009) Evolution of products during the degradation of polyethylene in a batch reactor. $\mathrm{J}$ Anal Appl Pyrolysis 86:14-21

23. Lovás P, Hudec P, Jambor B, Hájeková E, Hornacek M (2017) Catalytic cracking of heavy fractions from the pyrolysis of waste HDPE and PP. Fuel 203:244-252

24. Seo YH, Lee KH, Shin DH (2003) Investigation of catalytic degradation of high-density polyethylene by hydrocarbon group type analysis. J Anal Appl Pyrolysis 70:383-398

Publisher's Note Springer Nature remains neutral with regard to jurisdictional claims in published maps and institutional affiliations. 